\title{
DISCOVERY OF DOCUMENTS AND THINGS: THE FEDERAL RULES AND THE CALIFORNIA LAW
}

[This comment is one of a series being prepared by the lane reviews of California at the request of the State Bar of California to supplement the study being conducted as to the feasibility and desirability of incorporating certain of the Federal Rules of Civil Procedure into California practice.]

"Discovery" is the term applied to the means which a party to a pending action can employ before trial to compel an adverse party to divulge relevant facts and produce relevant documents and other tangible objects for inspection. This comment, which is limited to the document production aspect of discovery, is a comparison of the production devices available under the Federal Rules of Civil Procedure with those provided by the California law. ${ }^{1}$

DISCOVERY OF DOCUMENTS UNDER THE FEDERAI RULES

\section{The Motion for Production}

The theory underlying the liberal deposition-discovery procedure provided by Federal Rules $26-37$ is that "[m]utual knowledge of all relevant facts gathered by both parties is essential to proper litigation."2 The motion for production of documents under Rule $34^{3}$ is an important tool in the hands of the party seeking to uncover relevant facts. By this device, which may be utilized at any time after commencement of the action, ${ }^{4}$ an

1 Subsequent notes will compare the deposition under the California law with the federal deposition and written interrogatory and will compare sanctions for failure to comply with a proper demand for discovery in California and the federal practice. The federal rules relating to physical examination of parties and to admission of facts and genuineness of documents are compared with the California practice in Note, 42 CarrF. L. REv. 187 (1954).

2 Hickman v. Taylor, 329 U.S. 495, 507 (1947). The object of making all the facts available to the litigants is: (1) to narrow the issues formulated by the simplified pleadings permissible under the federal rules; (2) to provide evidence for use at the trial; (3) to minimize surprise at the trial. The question whether surprise is an aid or deterrent to the attainment of justice has been a source of controversy. See RAGLAND, Drscovery Before TrIax 263 (1932); Hawkins, Federal Discovery Procedure-Another Look at Rule 34, 25 TEx. I. REv. 267, 283-286 (1947) ; Hocker, How the Amended Discovery Rule Affects Relevance, 1948 INs. I.J. 793, 796800; Hawkins, Discovery and Rule 34: What's So Wrong About Surprise?, 39 A B.A.J. 1075 (1953) [note the reply at 40 A.B.A.J. 184 (1954)]; Virtue, Sweet Are the Uses of Discovery: $A$ Reply to Mr. Haveins, 40 A.B.A.J. 303 (1954); Jayne, Discovery: The Neve Michigan Rule, 40 A.B.A.J. 304 (1954); Hawkins, $A$ Surrejoinder to Judge Jayne, 40 A.B.A.J. 601 (1954) [note the reply at 40 A.B.A.J. 703 (1954)]. For a presentation of both sides of the argument See 6 WrGMIORE, EVIDENCE $\$ 1845$ (3d ed. 1940).

3 FED. R. CIV. P. 34: "Discovery and Production of Documents and Things for Inspection, Copying, or Photographing. Upon motion of any party showing good cause therefor and upon notice to all other parties, and subject to the provisions of Rule 30(b), the court in which an action is pending may (1) order any party to produce and permit the inspection and copying or photographing, by or on behalf of the moving party, of any designated documents, papers, books, accounts, Ietters, photographs, objects, or tangible things, not privileged, which constitute or contain evidence relating to any of the matters within the scope of the examination permitted by Rule $26(\mathrm{~b})$ and which are in his possession, custody, or control ...."

4 Courteau v. Interlake S.S. Co., 1 F.R.D. 525 (W.D. Mich. 1941). A few cases have held that the motion for production cannot be made until service of the answer. See, e.g., Hartford Nat. Bank \& Trust Co. v. E. F. Drew \& Co., 13 F.R.D. 127 (D. Del. 1952) ; Piest v. Tide Water Oil Co., 26 F.Supp. 295 (S.D. N.Y. 1938). 
adverse party may be compelled to produce for inspection and copying any relevant, non-privileged documents or objects which are in his possession, custody or control.

The documents sought must be "designated" in the motion for production. ${ }^{5}$ Some disagreement has arisen as to the degree of specificity required. A number of cases have held that each document sought must be designated, ${ }^{6}$ but the more liberal view adopted by many of the cases is that the designation may relate to particular categories, if defined so as to inform a reasonable man what documents are sought. ${ }^{7}$ Depositions ${ }^{8}$ and written interrogatories ${ }^{9}$ may be used to ascertain the fact of possession and obtain a description sufficient to support a motion for production.

Under the present wording of Rule 34 the scope of examination permitted is as broad as that under Rule $26(\mathrm{~b}) .{ }^{10}$ Thus the document sought must be relevant to the subject matter of the pending action, and the fact that it is inadmissible as evidence, assuming the reason to be one other than privilege, is not material if the document may reasonably be expected to lead to the discovery of admissible evidence. ${ }^{11}$

Rule 34 requires the moving party to show "good cause" for the production of the particular documents. ${ }^{12}$ While the indefiniteness of this requirement may be in keeping with the notion of flexibility and discretion inherent in the federal discovery procedure, it has produced much litigation and has provided courts with a ground for denying production that masks the rationale of the particular decision. ${ }^{13}$ The Advisory Committee is presently considering a proposal that the "good cause" requirement be dropped froin Rule $34 .{ }^{9}$

5 See note 3 supra.

6 E.g., United States v. American Optical Co, 2 F.R.D. 534 (S.D.N.Y. 1942); Welty v. Clute, 29 F.Supp. 2 (W.D.N.Y. 1939).

7 E.g., Hawaiian Airlines v. Trans-Pacific Airlines, 8 F.R.D. 449 (D. Hawaii 1948) ; United Mercantile Agencies v. Silver Fleet Motor Express, Inc., 1 F.R.D. 709 (W.D. Ky. 1941).

8 FED. R. CIV. P. 26.

9 FED. R. Crv. P. 33.

10 FED. R. Crv. P. 26(b): "[T] privileged, which is relevant to the subject matter involved in the pending action, whether it relates to the claim or defense of the examining party or to the clain or defense of any other party .... It is not ground for objection that the testimony will be madmissible at the trial if the testimony sought appears reasonably calculated to lead to the discovery of admissible evidence." Rule 34 originally provided that production could be compelled of documents "not privileged, which constitute or contain evidence material to any matter involved in the action ...." (italics added). As the Advisory Committee pointed out in its note to the 1946 amendment to the rule, the present language was substituted for the words italicized above in order to "correlate the scope of inquiry permitted under Rule 34 with that provided in Rule 26(b), and thus remove any ambiguity created by the former differences in language."

11 See Mackerer v. New York Cent. R.R., 1 F.R.D. 408 (E.D.N.Y. 1940).

12 See note 3 supra.

13 See Yudkin, Some Refinements in Federal Discovery Procedure, 11 FED. B.J. 289, 290293 (1951); Discovery Procedures in Trial Preparation, 28 CaxIF. ST. B.J. 400, 401 (1953). "Any attempt to harmonize the cases on 'good cause' would prove futile, and an attempt to analyze the cases serves only to focus attention upon their inconsistencies." Durkin v. Pet Milk Co., 14 F.R.D. 385,396 (1953).

14 Preitumara Draft of Proposed Amendments to Rules of Civis Procedure 31-32 (1954). 
Production will not be ordered if the document sought is privileged. ${ }^{15}$ However, a substantial part of the "work product" of an attorney falls outside the attorney-client privilege. The much discussed case of Hickman $v$. Taylor ${ }^{16}$ involved the question whether non-privileged trial preparations were subject to discovery under the federal rules. The Supreme Court, relying on "the general policy against invading the privacy of an attorney's course of preparation," 17 demed discovery of oral and written statements of non-party witnesses which had been obtained by defendant's counsel. The Court indicated, however, that this policy did not bar discovery where there was a showing that denial would unduly prejudice the moving party.

Although the deposition-discovery procedure under the rules seems to have worked quite well in most cases, some abuses have been noted. ${ }^{18}$ The motion for production appears less susceptible to misuse resulting in expense and delay than the deposition and, therefore, of less utility to the unscrupulous party seeking to force a settlement. In most cases the party from whom production is sought will be able to locate the desired documents and make them available to the moving party without expending an unreasonable amount of time or money. This is not always true, however. There is a danger that a party who has little to fear from retaliatory discovery may use extensive demands for production as well as lengthy depositions as a shake-down tactic. ${ }^{19}$

Two other possibilities for abuse of Rule 34 should be noted. One involves the use of discovery as a means for prying into the trade secrets of a conipetitor. ${ }^{20}$ The other arises from the fact that the party first obtaining discovery may, under certain circumstances, be presented with an opportunity to fabricate or destroy evidence. ${ }^{21}$

15 See note 3 supra. "[T] he term 'not privileged' as used in Rule 34, refers to 'privileges' as that term is understood in the law of evidence." United States v. Reynolds, 345 U.S. 1, 6 (1953). For a discussion of the tendency to hold documents in the possession of the United States immune froin discovery on the basis of a "governmental privilege" not coinprehended by the law of evidence, see 4 Moore, Federal Practice 1160-1182 (2d ed. 1950); Berger and Krash, Government Immunity from Discovery, 59 YaLE L.J. 1451 (1950); Comment, 13 OHIO ST.L.J. 270 (1952).

16329 U.S. 495 (1947) (although the discovery device involved was not a inotion for production, but a written interrogatory under Rule 33, the rule of the case is applicable to the entire discovery procedure under the federal rules). See 4 MoORE, FEderat Practice 10881152 (2d ed. 1950); Hawkins, Federal Discovery Procedure-Another Look at Rule 34, 25 Tex. L. Rev. 276, 283-286 (1947); Taine, Discovery of Trial Preparations in the Federal Courts, 50 Cor. L. Rev. 1026 (1950); Note, 62 HaRv. L. REv. 269 (1948); Discovery Procedures in Trial Preparation, 28 CAIIF. ST. B.J. 400 (1953).

17 Hickman v. Taylor, 329 U.S. 495, 512 (1947).

18 See Yudkin, Some Refinements in Federal Discovery Procedure, 11 FED. B.J. 289, 290293 (1951); Coniment, 59 Yare L.J. 117 (1949); Note, 36 MnNN. L. REv. 364 (1952).

19 The stockholders derivative suit often presents an opportunity for this type of abuse. See Comnient, 59 YaLE L.J. 117, 128-129 (1949).

20 See Conument, 59 Yare L.J. 117, 136-138 (1949).

21 For exanple, in a patent case where prior knowledge and use is an issue, the party who first utilizes discovery to ascertain the dates on which his adversary will rely is provided with an opportunity to fabricate evidence establishing his own priority. See Yudkin, Some Refinements in Federal Discovery Procedure, 11 FED. B.J. 289, 297-301 (1951), for a full discussion of the various nianifestations of this problen. The writer points out that a nunber of courts have avoided the danger of abuse in patent cases by requiring simultaneous disclosure, but feels that too little attention has been given this problem in other types of hitigation. 
If, as some commentators suggest, ${ }^{22}$ the courts have not provided adequate protection against abuses, it is not because they lack the power to make adjustments in the discovery procedure. Rule $30(\mathrm{~b}),{ }^{23}$ which is incorporated into Rule 34 , not only provides a number of specific protective orders which a court can make, but authorizes "any other order which justice requires to protect the party or witness from annoyance, embarrass. ment, or oppression."2t

\section{Discovery of Documents Under Rule 33}

In a number of cases a party serving written interrogatories on his adversary under Rule 33 has included a request that copies of relevant documents be attached to the answers. Most district courts have refused to enforce such requests, ${ }^{25}$ but a few have taken the liberal view that where it is apparent that the party seeking production of the copy could meet the "good cause" requirement under Rule 34, the formality of a motion under that rule will not be required..$^{26}$ In Alltmont v. United States, ${ }^{27}$ the Court of Appeals for the Third Circuit followed the narrow view and held that the party seeking discovery must resort to Rule 34 . The recent Preliminary Draft of Proposed Amendments includes an amendment to Rule 33 which would permit the imterrogatory to be used for the purpose of obtaining copies of documents "unless opportunity for their examination and copying be afforded." 28 This is consistent with the proposed amendment to Rule 34 which would eliminate the "good cause" requirement. ${ }^{29}$

\section{The Subpoena Duces Tecum}

Rule $45,{ }^{30}$ which provides that a subpoena duces tecum may issue in connection with the taking of a deposition, affords another means for com-

22 Yudkin, Some Refinements in Federal Discovery Procedure, 11 Fed. B.J. 289 (1951); Comment, 59 Yare L.J. 117 (1949).

23 FED. R. CTV. P. 30(b): "[T]he court in which the action is pending may make an order .. that certain matters shall not be imquired into, or that the scope of the examination shall be limited to certain matters, or that the examination shall be held with no one present except the parties to the action and their officers or counsel, or that . . . secret processes, developments, or research need not be disclosed, or that the parties shall simultaneously file specified documents or information enelosed in sealed envelopes to he opened as directed by the court; or the court may make any other order which justice requires to protect the party or witness from annoyance, embarrassment, or oppression."

24. The Preltminary Draft of Proposed Amendarents to the Rules (1954) inserts the words "undue expense" following the word "annoyance."

25 E.g., Borgen v. Penn. Greyhound Lines, Inc., 9 F.R.D. 209 (N.E. Ohio 1949); Castro v. A. H. Bull \& Co., 9 F.R.D. 84 (S.D.N.Y. 1949).

${ }_{26}$ E.g., Alfred Pearson \& Co. v. Hayes, 9 F.R.D. 210 (S.D.N.Y. 1949); Doman v. Isthmian Steamship Co., 6 F.R.D. 609 (E.D.Pa. 1945). See also Maddox v. Wright, 11 F.R.D. 170 (D.D.C. 1951). Some courts have drawn a distinction between imterrogatories calling for a copy of a document and those requesting a copy of the statement of a witness on the ground that in the latter case the party is actually seeking to ascertain the facts which the witness gave the adverse party. See, e.g., DeBruce v. Penn. R.R., 6 F.R.D. 403 (E.D.Pa. 1947).

27177 F.2d 971 (3d Cir. 1949), cert. denied, 339 U.S. 967 (1950).

28 Prelimmary Draft of Proposed Amendanents to the Rules of Civil Procedure 28-30 (1954).

29 See text at note 14 supra.

30 FED. R. Crv. P. 45(d) (1): "Proof of service of a notice to take a deposition . . . constitutes a sufficient authorization for the issuance by the clerk of the district court . . . of sub- 
pelling an adverse party to produce relevant documents prior to trial. This device is somewhat broader than the motion for production under Rule 34 since it may be used to compel production of documents in the possession of a non-party witness as well as those in the hands of an adverse party. ${ }^{31}$

Rule 45 originally required a court order for the issuance of a subpoena duces tecum, but the 1946 amendment to the rule provides that it shall issue as a matter of course from the clerk. ${ }^{32}$ In order to contest the issuance, a motion to quash or modify the subpoena may be made. ${ }^{33}$

The requirements imposed by Rule 34 are also applicable to the subpoena duces tecum and may be considered on a motion for relief. Thus the documents sought must be in the possession or control of the person to whom the subpoena is directed; ${ }^{34}$ they must be designated with a reasonable degree of particularity; ${ }^{35}$ and while they need not be admissible as evidence if they may be expected to provide leads to admissible evidence, they must be relevant to the subject matter of the action. ${ }^{36}$ The documents must not be privileged, ${ }^{37}$ and the limitations imposed by Hickman v. Tay$l o r^{38}$ on the discovery of documents representing the "work product" of an attorney are no doubt applicable. Several recent cases have held that lack of "good cause" for production is also a ground for quashing a subpoena duces tecum. ${ }^{39}$

In addition, Rule 45(b) provides certain discretionary relief. The court, upon motion, may:

(1) quash or modify the subpoena if it is unreasonable and oppressive or

(2) condition denial of the motion upon the advancement by the person in whose behalf the subpoena is issued of the reasonable cost of producing the books, papers, documents, or tangible things.

\section{DISCOVERY OF DOCUMENTS UNDER CALIFORNIA LAW}

\section{The Motion for Production}

Section 1000 of the Code of Civil Procedure ${ }^{40}$ provides that a court may order either party to produce for inspection and copying by the adverse

poenas for the persons named or described therein. The subpoena may command the person to whom it is directed to produce designated books, papers, documents, or tangible things which constitute or contain evidence relating to any of the matters within the scope of the examination permitted by Rule $26(\mathrm{~b})$...."

81 Eastern States Petroleum Co. v. Asiatic Petroleum Corp., 27 F.Supp. 121 (S.D.N.Y. 1938).

32 See note 30 supra.

33 North v. Lehigh Valley Transit Co., 10 F.R.D. 38 (E.D.Pa.1950).

34 Fox v. House, 29 F.Supp. 673 (E.D. Okla. 1939).

35 Hercules Powder Co. v. Rohm \& Haas Co., 3 F.R.D. 302 (D. Del. 1943).

30 lbid.

37 See Ulrich v. Ethyl Gasoline Corp., 2 F.R.D. 357, 360 (W.D. Ky. 1942).

38 See text at notes 16-17 supra.

30 Demeulenaere v. Rockwell Mfg. Co., 13 F.R.D. 134 (S.D.N.Y.1952), citing 5 Moore, Federal Practice 1722-1723 (2d ed. 1950); Sagorsky v. Malyon, 12 F.R.D. 486 (S.D.N.Y. 1952).

40 Cad. Code Crv. Proc. \$1000: "Any court in which an action is pending, or a judge thereof may, upon notice, order cither party to give to the other, within a specified time, an inspection and copy or permission to take a copy, of entries of accounts in any book, or of any document or paper in his possession, or under his control, containing evidence relating to the 
party "any document or paper in his possession, or under his control, containing evidence relating to the merits of the action, or the defense therein." "11 Unlike Rule 34, this section does not expressly apply to tangible objects other than documents. It has been held, however, that a court has inlierent power to order an inspection of tangible property. ${ }^{42}$

The documents sought must be designated, but "it is sufficient if they are identified by a description that can be reasonably understood by the adverse party." 43 In Union Trust Co. v. Superior Court, ${ }^{44}$ the supreme court held, in effect, that designation by categories was sufficient if, under the circumstances, the custodian of the documents should recognize the particular ones desired. ${ }^{45}$ Thus there seems to be little, if any, difference between the California law and the federal rules as to the designation requirement. ${ }^{48}$

As pointed out above, Rule 34 makes a showing of "good cause" a prerequisite to production. ${ }^{47}$ Section 1000 of the Code of Civil Procedure, on the other hand, does not require an affirmative showing of justification for production. The court, however, has the discretion to deny the motion if it appears that the inspection is not necessary to the preparation and proof of the moving party's case. ${ }^{48}$

The most significant difference between Section 1000 and Rule 34 is in the scope of discovery permitted. Under Rule 34 a document need not be admissible as evidence; if it is relevant to the subject matter of the action, non-privileged, and appears likely to lead to the discovery of admissible evidence, discovery will be allowed. ${ }^{49}$ The California law requires that the document sought contain "competent and admissible evidence which is material to the issues to be tried." The moving party must

merits of the action, or the defense therein. If compliance with the order be refused, the court may exclude the entries of accounts of the book, or the document, or paper from being given in evidence, or if wanted as evidence by the party applying may direct the jury to presume them to be such as he alleges thein to be; and the court may also punish the party refusing for a contempt. This section is not to be construed to prevent a party from compelling another to produce books, papers, or documents when he is examined as a witness."

41 Section 1000 of the Code of Civil Procedure provides several sanctions which may be applied in the case of a refusal to comply with an order of production. Sce the discussion in Harkelroad, The Law of Discovery in the Courts of California, 4 So. CaLtr. L. REv. 169, 180 (1931). A federal court, however, is given much broader power in such a case by Federal Rule 37. A subsequent note will compare the two practices.

42 Clark v. Tulare Lake Dredging Co., 14 Cal. App. 414, 437, 112 Pac. 564, 574 (1910).

43 McClatchy Newspapers v. Superior Court, 26 Cal. 2d 386, 397, 159 P.2d 944, 950 (1945).

4411 Cal.2d 449, 81 P.2d 150 (1938).

45 While it is possible to interpret McClatchy Newspapers v. Superior Court, $26 \mathrm{Cal}$. 2d 386, 159 P.2d 944 (1945), as requiring a more specific designation tban the Union Trust case, it appears that the court in McClatchy was primarily concerned with the inadequate showing of materiality rather than with insufficient designation.

46 Sce text at notes 5-7 supra.

47 See text at notes 12-14 supra.

48 Maclay Rancho v. Superior Court, 81 Cal. App. 471, 254 Pac. 287 (1927).

49 See text at notes 10-11 supra.

50 McClatchy Newspapers v. Superior Court, 26 Cal.2d 386, 396, 159 P.2d 944, 950 (1945). While the Cahifornia practice imposes stricter limitations on the production of documents before the trial of a pending action than the federal rules, the California provision for perpetuation of testimony before commencement of an action is much more liberal than Federal Rule 27. See the discussion in Comment, 3 Stan. L. Rev. 530 (1951). 
"clearly show" the presence of such evidence; he "cannot rely merely upon the legal conclusion, stated in general terms, that the desired documentary evidence is relevant and material." ${ }^{51}$ This showing is a big hurdle in the path of one seeking production. ${ }^{52}$

Privilege is a bar to discovery under both the California law and the federal rules. The first case to apply this limitation to a motion for production under Section 1000 of the Code of Civil Procedure was recently decided by the California Supreme Court. ${ }^{53}$ A somewhat broader scope was given the attorney-client privilege by the court than that applied by most recent federal decisions. ${ }^{54}$

\section{The Subpoena Duces Tecum}

The subpoena duces tecum, which issues from the clerk in connection with the taking of a deposition, is the second means provided by the California law for compelling production of documents prior to trial. ${ }^{55}$ As in the case of a motion for production, the documents sought must be sufficiently designated, and a clear showing must be made that they contain matter which is admissible. ${ }^{56}$

Under both California law and the federal rules, the motion for production is limited to documents in the possession or control of an adverse party. This limitation, however, does not extend to the subpoena duces tecum. ${ }^{57}$ The federal rules provide that relevant documents in the hands of any person may be subpoenaed. ${ }^{58}$ The California rule is not this broad. Section 1985 of the Code of Civil Procedure provides that the means for compelling a witness to attend and testify is the subpoena, and that " $[\mathrm{i}] \mathrm{t}$

51 McClatchy Newspapers v. Superior Court, supra note 50 at 396, 159 P.2d at 950; Kullman, Salz \& Co. v. Superior Court, 15 Cal. App.2d 286, 114 Pac. 589, 593 (1911) (requiring the showing to be inade by "clear and unequivocal proof" in the form of competent evidence).

52 In order to ascertain facts upon which to base a motion for production, the deposition of an adverse party may be taken. See McClatchy Newspapers v. Superior Court, 26 Cal. 2d 386, 398, 159 P.2d 944, 951 (1945); Funkenstein v. Superior Court, 23 Cal. App. 663, 667, 139 Pac. 101, 103 (1914). Whether the deposition of a non-party witness may be used for discovery is not clear. See note 59 infra.

53 Holm v. Superior Court, 42 Cal.2d 500, 267, P.2d 1025 (1954) (Justices Traynor and Carter dissenting). The case is discussed in Note, 1 U.C.L.A. L. Rev. 605 (1954).

54 See, e.g., Herbst v. Chicago, R.I. \& P. R.R., 10 F.R.D. 14 (S.D. Iowa 1950) ; Morrone v. Southern Pacific Co., 7 F.R.D. 214 (S.D. Cal. 1947).

55 Cal. Code Crv. Proc. \$1985: "The process by which the attendance of a witness is required is the subpoena. ... It may also require him to bring with him any books, documents or other things under his control which he is bound by law to produce in evidence.

"All apphications before trial for subpoenas duces tecum shall be accoinpanied by an affdavit specifying the exact matters or things desired to be produced, and setting forth in full detail the materiality thereof to the issues involved in the case, and stating that the witness has the desired matters or things in his possession or under his control."

In addition to its use in connection with the deposition, the subpoena duces tecum is available as a means for compelling production of documents at the trial.

56 See note 55 supra. McClatchy Newspapers v. Superior Court, 26 Cal.2d 386, 398, 159 P.2d 944, 951 (1945).

57 See text at note 31 supra (discussion of subpoena duces tecum under the federal rules); McClatchy Newspapers v. Superior Court, 26 Cal.2d 386, 398, 159 P.2d 944, 951 (1945) (subpoena duces tecum of a non-party witness under the California law).

68 FED. R. CIV. P. 26, 45. 
may also require him to bring with him any books, documents, or other things under his control which he is bound by law to produce in evidence." Section 2021 limits a party's right to take the deposition of a non-party witness to certain cases. ${ }^{59}$ It necessarily follows that where the taking of a deposition is prohibited, one may not obtain a subpoena duces tecum ordering production prior to the trial..$^{60}$

\section{CONCLUSION}

While the general scheme for obtaining production of documents by an adverse party under Section 1000 of the Code of Civil Procedure is similar to that provided by Federal Rule 34, there are two significant differences: (1) Rule 34, unlike Section 1000, requires an affirmative showing of "good cause" by the moving party; (2) the scope of permitted discovery is much broader under Rule 34, madmissibility not being a bar to discovery as it is under Section 1000.

Under both federal and California practice, the device for reaching docuinents in the hands of non-party witnesses is the subpoena duces tecum. Federal Rule 45 permits discovery of documents in the hands of any person, but under California law the subpoena duces tecum is available only against certain types of non-party witnesses.

The Committee on Federal Rules of the Conference of State Bar Delegates has recommended that the legislature enact a statute based upon Rule $34 .^{61}$ No change is recommended in the code provisions relating to

50 Most of the situations in which the deposition of a non-party witness may be taken fall roughly into two groups: (1) cases where the witness is the agent or employee of a party ; (2) cases involving a possibility that the testimony of the witness will not be available at the trial.

It is not clear whether such a deposition may properly be used for the purpose of discovery as well as to preserve testimony for the trial. Compare the statements in Ahern v. Superior Court, 112 Cal. App.2d 27, 31, 245 P.2d 568, 571 (1952), and Verdier v. Superior Court, 88 Cal. App.2d 527, 535, 199 P.2d 325, 330 (1948), with the dicta in McClatchy Newspapers v. Superior Court, 26 Cal.2d 386, 394, 398-399, 159 P.2d 944, 948-949, 951 (1945), and Carnation Co. v. Superior Court, 96 Cal. App.2d 138, 140, 214 P.2d 552, 553 (1950).

60 Impliedly supporting this construction is Nelson v. Superior Court, $9 \mathrm{Cal} .2 \mathrm{~d} 729,73$ P.2d 232 (1937).

61 The text of the proposed section is as follows: "Discovery and Production of Documents and Things For Inspection, Copying or Photographing. (a) Upon motion of any party showing good cause therefor, and upon at least ten (10) days' notice to all other parties, and subject to the provisions of subsection (b) hereof, the court in which any action is pending may (1) order any party to produce and permit the inspection and copying or photographing, by or on behalf of the moving party, of any designated documents, papers, books, accounts, letters, photographs, objects, or tangible things, not privileged, which constitute or contain evidence relating to any of the matters within the scope of the examination permitted by subsection (c) hercof and which are in his custody or control; or (2) order any party to permit entry upon designated land or other property in his possession or control for the purpose of inspecting, measuring, surveying, or photographing the property or any designated object or operation thcreon within the scope of the examination permitted by subsection (c) hereof. The order shall spccify the time, place, and manner of making the inspection and taking copies and photographs and may prescribe such terms and conditions as are just. This section shall not apply to memoranda, reports or documents prepared by the attorney for either party in preparation for trial, or any communications between any party or his agent and the attorney for said party.

"(b) After notice is served under subsection (a) hereof, upon motion seasonably made by any party and upon notice and for good cause shown, the court in which the action is pending may make an order that certain matters shall not be inquired into, or that the scope of the 
depositions and subpoenas duces tecum. Thus the proposed legislation would liberalize the present California law regarding discovery of documents in the hands of an adverse party without affecting the law which limits discovery of documents held by a non-party witness.

Donald L. Edgar

examination shall be limited to certain matters, or that the examination shall be held with no one present except the parties to the action and their officers or counsel, or that secret processes, developments, or research need not be disclosed, or that the parties shall simultaneously file specified documents or information in sealed envelopes to be opened as directed by the court; or the court may make any other order which justice requires to protect the party from annoyance, embarrassment or oppression.

"(c) Unless otherwise ordered by the court, as provided in subsection (b) hereof, this section shall apply to any matter, not privileged, which is relevant to the subject matter involved in the pending action, whether it relates to the claim or the defense of the examining party or to the claim or the defense of any other party, including the existence, description, nature, custody, condition and location of any books, documents, or tangible things and the identity and location of persons having knowledge of relevant facts. It is not ground for objection that the testimony ehicited under this section will be madmissible at the trial if the testimony sought appears reasonably calculated to lead to the discovery of admissible evidence.

"(d) Nothing contained in this section or any subsection hereof shall be construed as repealing by implication or otherwise any statutory or other right given any party for production of evidence; it being the intention hereof that the provisions for the production of evidence contained in this section shall be in addition to, and not in substitution of, any presently existing right." 